\title{
Canadian Horror, American Bodies: Corporeal Obsession and Cultural Projection in American Nightmare, American PSycho, and American Mary
}

\begin{abstract}
Many Canadian horror films are set in the United States and claim to provide a graphic critique of typically American social problems. Using three made-in-Canada films that explicitly situate themselves "south of the border," - American Nightmare" (1983, Don McBrearty), "American Psycho" (2000, Mary Harron), and "American Mary" (2012, Jen Soska and Sylvia Soska) - this essay argues that these and other similar cinematic tales of terror have less to do with America than with Canada's own national anxieties. These films project Canadian fears onto the United States to avoid facing our national implication in horror, mayhem and chaos; and more often than not, the body is the preferred site of such projection. In this way, such films unwittingly expose Canada's dark obsessions through cultural displacement. Ultimately, this article suggest that Canadians have a long way to go before they can stop blaming the American monster for everything bad that happens to them, and finally dare to embrace their own demons.
\end{abstract}

\section{Key words}

Canadian horror films; the body as site of terror; Imaginary Canadian; Canada-US relationship; Toronto and Vancouver masquerading as American cities

Canadian comedian Martin Short was once asked by American late-night TV show host David Letterman what is the difference between the inhabitants of the two neighboring nations. In what is probably the most accurately pithy answer to this eternal question, Short wittily replied, "Americans watch TV, Canadians watch American TV" (Pevere 1998: 10). While obviously an oversimplification 
of a very complex issue, Short's aphorism still conveys Canadians' inexorable fascination with the deeply seductive televised images of the American dream come true. But those images are equally repulsive to many Canadians, for they also evoke the penumbra; the shattering effects of a dream gone horribly wrong. The allure of excessive wealth is thwarted by the sight of extreme poverty. The appeal of unwavering self-confidence is dismayed by the dread of rabid religiosity. The glamour of unshakable resolve is smeared by devastating violence. We envy boundless American audacity at the same time as we fear brutal American recklessness. For many Canadians, America is an awesome creature that mixes colossal promise with apocalyptic scourge. It is not surprising, then, that when Canadian filmmakers choose to confront their own demons in the form of horror films they often transpose the action onto American soil: the land of glamorous monsters. From David Cronenberg's The Fly (1986) to Peter Cornwell's The Haunting in Connecticut (2009), Canada often masquerades as the US, as the site of righteous dread and dazzling anguish.

There is something typically Canadian in this hypocritical projection of our fears onto the United States; and more often than not, the body is the preferred site of such projection. For the body stands as a perfect incarnation of the radical American paradoxes that so fascinate the prudent people of Canada. From the sublime physique of the Hollywood Adonis to the grotesque figures that haunt the Walmarts of the Midwest, ${ }^{1}$ the body incarnates the ideals that inspire us all as well as the devastating failures that petrify us. This essay examines three horror films made in Canada, which focus on American corporality as the embodiment of the abjection that Canadians deny in themselves and project onto the monstrous US. American Nightmare (1983, Don McBrearty) examines the exploited body that reduces people, and women in particular, to objects to be bought and

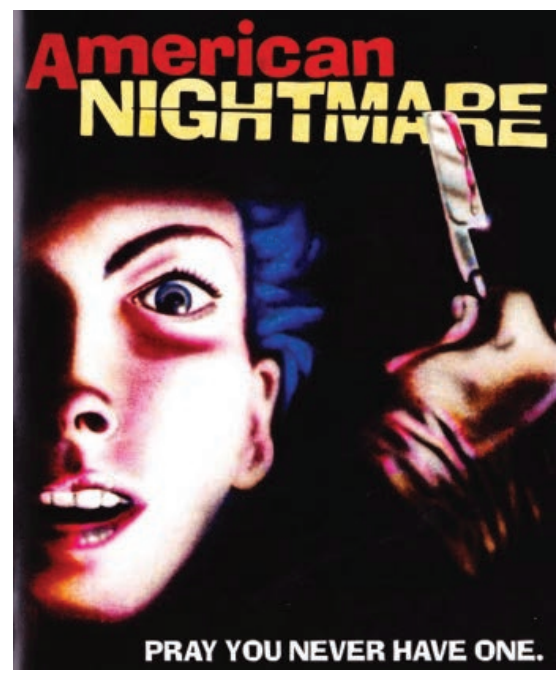

Figure 1. American Nightmare Poster 
sold; American Psycho (2000, Mary Harron) showcases the body as the archconsumer who consumes other bodies; and American Mary (2012, Jen Soska and Sylvia Soska) exposes the misguided search for perfection through bodymodification. That recognizable Canadian locations incarnate American cities in all three films (Toronto in the first two and Vancouver in the third) is significant here, for it manifests the "Canadianness" of the terrors incited by the films. While these are horror stories set in the US, the films make clear that they are fundamentally about Canadian fears. This is nowhere more evident than in American Nightmare, in which a barely disguised Toronto is the obvious locale where the "typically American" problem of sexual enslavement transpires.

The film revolves around Eric Blake (Lawrence Day), a successful pianist who explores the seedier parts of the big city - sometimes referred to by reviewers as New York City ${ }^{2}$ but never explicitly identified as such in the film - in search of his runaway sister, Isabelle (Alexandra Paul). Meanwhile, a serial killer roams the same sordid neighborhoods, stabbing and strangling strippers, prostitutes and drag queens. In the end, the killer is revealed to be Tony Shaw (Neil Dainard), the trusted right-hand man of Eric's father, Hamilton Blake (Tom Harvey). Blake senior is a media mogul who sponsors the save-the-children telethon "Unisave" at the same time as he is sexually obsessed with his own daughter and videotapes his incestual exploits. Isabelle and a few annoying witnesses are disposed of by the ever-devoted Tony when videos of Hamilton's indiscretions threaten to ruin his image as a great TV humanitarian.

American Nightmare, a North American variation on the well-known Italian giallo genre, uses the pretext of a righteous investigation into the sleazy underworld to indulge in graphic displays of sex and violence. Much of Don McBrearty's movie is occupied by vignettes of strippers taking off their clothes for the viewing pleasure of patrons within the diegesis and spectators watching the film. In most cases, no sooner have their bodies been displayed in the nude for our enjoyment that the strippers are brutally murdered by gloved hands emerging from dark corners. Not coincidently, the strippers are not incarnated by charismatic movie stars with whom the audience would become enthralled. Rather, the actresses are generally nondescript and give indifferent performances as exotic dancers who can easily be objectified as nameless bodies that are unceremoniously displayed and quickly discarded. As yet another lifeless corpse is found in a pile of trash, one can almost see spectators paradoxically recoiling in disgust before this senseless carnage, at the same time as they smirk approvingly at this well-deserved retribution for the victim's skanky ways. Like most slashers, American Nightmare playfully indulges in the spectacle that it so self-righteously denounces.

The duplicitous irony is all the more striking that it is a Canadian film that so overtly exploits the degenerate pleasures of American corporeal depravity. As Rhett Miller writes in his review of American Nightmare,

The film's America is truly a nightmare one where women are subjugated, even exploited, for empty male pleasures. The entire film is filtered through 
an unwavering male gaze: the men watch the girls dance at seedy bars, the men videotape their sexual conquests on video, and applicants for the UNISAVE program are even made to strip in front of the cameras (Miller).

With its unambiguous title and numerous references to Chicago, Detroit and MTV, McBrearty's film presents itself as a biting critique of American sexploitation, where the female body is systematically emptied of its human essence and unrestrainedly reified as an erotic puppet displayed for male pleasure.

What is most remarkable about the film, however, is that its gruesome American setting is so recognizably Canadian. As Eric moves through the city in search of his sister, numerous Toronto landmarks appear in full view. Most strikingly, in the final confrontation between Eric and Tony, the CN Tower conspicuously looms in the background. For anyone even remotely familiar with this cityscape, the setting is impossible to mistake for New York, Chicago or Detroit. And if this were not enough, McBrearty also offers us a cameo appearance by Paul Bradley, a minor actor celebrated for one role, and one role only: Joey, the likable doofus from Don Shebib's milestone Toronto film, Goin' down the Road (1970). That a film entitled American Nightmare would be so recognizably Canadian is crucial here, for it manifests the tendency common in the horror film to project onto the other (America) the unbearable abjection that is excruciatingly intolerable in the self (Canada). As such, American Nightmare is a prototypical example of Canadian horror, where the monstrous "return of the repressed," which seeps through the cracks of self-righteous anti-Americanism, embodies the recognition that - all proportions kept - Canada is just as exploitative, seedy and depraved as its neighbor to the South. Like any fantastical creature, Canada's America in American Nightmare is but an uncanny reflection of our own corporeal obsessions and carnal barbarism. It is especially significant that this film, which points a judgmental finger towards America, would have been produced in Toronto in the early 1980 s.

Starting in the late $19^{\text {th }}$ century and through most of the $20^{\text {th }}$ century, "Toronto the Good" 3 was seen as the virtuous and sensible counterpart to her slutty and fickle older sister, Montreal. Propriety, respectability and decency were the most valued qualities of the complacently lackluster and proudly repressed English Canadian metropolis. By the 1970s, however, Toronto's squeaky-clean image was starting to tarnish significantly due, among other things, to an increasingly visible sex trade and increasingly sensationalistic headlines about murder and mayhem in the Queen City. In 1971, the Toronto Star featured a cautionary tale on the Catholic Church's repeated warnings that "sex shops and pornographic bookstores are destroying Toronto the Good" (Micallef 2010: 21). By the late 1970s, Toronto's main drag, Yonge Street, was slowly becoming a place as horrid and scary as anything you would find in any big American city. The ghastly story of a 12 year old shoeshine boy, who was kidnapped late at night on Yonge, raped multiple times and murdered, made all the headlines and shocked self-righteous Torontonians. As Sam Sutherland writes, 
"Victim of a sex orgy - Boy was drowned in a sink," screamed the front page of the Toronto Star on August 2, 1977. The shock to "Toronto the Good" was widespread and overpowering, shaking awake a slumbering Victorian colony that refused to accept the grim reality of the country's sleaziest strip. (Sutherland 2012: 185)

There was a perception in the 1970s and early 1980s that the city's wholesome image was being challenged, and that the monster of ugly American excess was threatening its pleasantly boring normality. Toronto's reaction at the time was thus to repress its own demons and project them onto the other - never a good idea, for the repressed will always return to bite you...

American Nightmare, therefore, is not about America at all. Rather, it is overtly about Canada, or at least its largest city, which at the time of the film's production, had become unable to deal with its deep implication in rampant physical abuse and bodily exploitation. Thus Toronto chose to create a monstrous scapegoat upon which it could project its anxieties. ${ }^{4}$ To this day, the big city has had difficulties accepting that it has the same "wicked problems" other large cities have. As recently as 2010, when the G-20 Summit led to unprecedented police violence and wide-spread vandalism in the city, "Toronto the Good" still felt under attack from bad external influences. Most Torontonians, in a state of denial, could not believe that something like this could possibly happen in their quiet little megacity (Agrell 2010: A10). Similarly, recent gang shootings have also led shocked Torontonians to shake their heads in disbelief and cry: "This isn't Toronto-the-Good anymore" ("This isn't Toronto the Good anymore", 2009: A15).

To be fair, one must recognize that Toronto has matured significantly over the past few decades and has shown a greater ability to accept that it has very serious problems, rather than just repressing them behind a veil of banal respectability. A 2006 article from Toronto Star attests to this effort to face the reality:

This week alone, a transit strike and three days of choking smog did little to rehabilitate our city's character. Add to this a litany of gang violence, a homeless problem and littered streets that we once boasted were spotless, and it's clear that the old monikers that were frequently attached to Toronto, as well as the city's former tourist slogans, now no longer apply. Here's our first attempt at updating them: Toronto the Good [becomes] Toronto the So Bad It's Good ("Welcome to the Big Smog," 2006: H03).

Toronto has long surpassed Montreal as Canada's economic centre and has become a thriving North American socio-cultural hub. But it has also become increasingly generic; an all-purpose American city consumed with consumerism and characterized by the type of entrepreneurial placelessness that unavoidably results from the global spread of neoliberal capitalism. Like most standard American cities, Toronto now even has its own wild-and-crazy mayor, Rob Ford, who replicates paragons of American political luridness such as Washington DC's 
crack-smoking Marion Barry, Detroit's racketeering Kwame Kilpatrick, and San Diego's sex-crazed Bob Filner. "Ro Fo", for a brief period of time in 2013-14 the ludicrous darling of American late-night television, is a far cry from the cornerstone of traditional Canadian politics: "peace, order and good government." $\mathrm{He}$ is just another "American Idiot", to quote Green Day.

Discussing the films of the 1990s "Toronto New Wave" cineastes, especially Atom Egoyan, Brenda Longfellow argues that what makes those productions distinctive is precisely their emphasis on the undistinguishable character of the big Canadian city as an American cosmopolitan centre of consumerist anonymity. This conception of Toronto as a generic space of urban placelessness is

crucial to understanding the films as complex mediations of a new social situation, in which the very terms of the social have expanded to include an international network of economic and cultural flows of products and influences. [... Toronto reflects] Fredric Jameson's theorization of a new cultural logic of late capitalism characterized, as he so famously claimed, by the absence of affect, the preference for surface, not depth, the absence of interiority, the effacing of history, a sense of placelessness and a diffused experience of space. It is hard to think of a cultural theory that could be any more isomorphic with the textual practices of Egoyan's early films (Longfellow 2006: 187).

It would also be hard to think of a better description for Mary Harron's adaptation of Bret Easton Ellis's 1989 American Psycho, a text that is deeply entrenched in a vision of terrifyingly exhilarating postmodern consumerism. I will not reproduce here the numerous debates around the comparative quality of the adaptation, which many critics found superior to the original "because it more sharply and clearly criticized American cultural values and put the novel's violence in a more ironic context" (Derry 2009: 171). Rather, for the purpose of this article I will focus on the cinematic representation of the body, especially the body of the protagonist, Patrick Bateman, as the incarnation of the endless interchangeability of commodities within rampant consumerism.

Since the end of the 1980s, the time of American Psycho's scandalous first print, there has been a sense that the Western world (if not the entire world) has been lost in a vortex of endless consumption where the commodity itself has lost all intrinsic value as an object and is appreciated only as a temporary place-holder to be quickly replaced by another equally worthless but probably more expensive commodity. As Simon Malpas writes in The Postmodern (2005),

the transformation of social experience into an interchangeable flow of commodities in which everything is up for sale produces a loss of reality that is at once terrifying and euphoric. There is no longer any firm ground for experience as customs and traditions are continually cast aside with the advent of new fashionable lifestyle choices. We become no more than the 
sum total of our purchases, and the feeling associated with this is one of a "heightened intensity" of experience suffused with a "mystical charge" as it veers schizophrenically between intoxication and anxiety. [...] Trapped in its schizophrenic depthlessness, in which all objects from food to fashion have become interchangeable commodities, the traditional grounds of cultural context, custom, class and even family organization have been swept from beneath our feet (Malpas 2005: 120).

Toronto, as a generic city that can stand for any number of other generic cities, perfectly embodies this "interchangeable flow of commodities in which everything is up for sale." More to the point of this essay however, it is the body of Patrick Bateman himself, played by an awkwardly perfect Christian Bale, that best personifies the interchangeable site of consumption. Bateman is a high-rolling, Wall Street yuppie, who is obsessed with his physical appearance, spends his days eating in exclusive restaurants and buying expensive clothes, and at night savagely decapitates business rivals and annoying girlfriends - or so we are led to believe. His body is the central metaphor of the satire, depicted at once as a temple of aesthetic perfection and as an empty shell that can be cast out and indistinguishably replaced.

This interchangeability is signified throughout the film, as Bateman and his yuppie friends systematically fail to recognize one another. "Is that Reed Robinson over there?" asks one generic young executive in the film's opening scene in a chic Manhattan restaurant. "It's not Reed Robinson... it's Paul Allen," responds another. "It's not Paul Allen," chimes in Patrick, shortly before they all throw their identical credit cards on the table to cover their $\$ 570$ lunch. Misrecognition is central to the film's horror effect. Not knowing "who's who" and "who does what" generates a profound sense of epistemological panic in the audience. The spectator is left without any recognizable moral or emotional anchor to cling to within the film's diegesis. Patrick himself is misrecognized when, in the film's climactic moment he tries to confess to his lawyer about the series of murders he thinks he has committed, including that of Paul Allen. But his lawyer fails to recognize him, assuming he is some other generic yuppie called Davis.

Patrick: Don't you know who I am? I'm not Davis. I'm Patrick Bateman. We talk on the phone all the time. Don't you recognize me? You're my lawyer. Now, Carnes, listen. Listen very, very carefully. I killed Paul Allen, and I liked it. I can't make myself any clearer.

Lawyer: But that's simply not possible. And I don't find this funny anymore. Patrick: It never was supposed to be. Why isn't it possible?

Lawyer: It's just not.

Patrick: Why not, you stupid bastard?

Lawyer: Because I had dinner with Paul Allen... twice in London just ten days ago. 
It is no coincidence that the notion of misrecognition would be central to a film in which mirror images are omnipresent. Narcissistic Bateman constantly looks at himself in the mirror where, if Jacques Lacan is to be believed, he systematically misrecognizes his image as his actual self. It is no coincidence either that a character so fixated on the imaginary would in fact imagine that he has committed dozens of murders, while in reality there is no evidence he has perpetrated any crime. Significantly, while the film - the imaginary signifier par excellence makes it clear that Bateman imagined all those crimes, the novel remains deeply ambivalent on the question. Most readers are left wondering what actually happened. Carl Tighe's reading of Bateman's failed confession in the novel is typical of this narrative uncertainty.

Bateman's confession not only goes badly awry, but Carnes then tells him that it is impossible that anybody has killed Paul Owen [sic - Allen in the film] because he had dinner with Owen "twice" just a few days ago in London. Bateman is also visited in his office by a detective investigating Owen's disappearance, but the detective says he suspects Owen is just avoiding his girlfriend since he owes her money and has been seen in London by a yuppie called Stephen Hughes. However, the detective also reveals that upon investigation Hughes had mistaken Hubert Ainsworth for Owen (Ellis 1991: 273). The effect of this confusion, combined with Bateman's admission that the deaths have not been reported in the press, throws the whole narrative into doubt. Has Bateman really been committing murders, or has he been imagining them? Is he a reliable narrator? We only ever have his word. Did Carnes have lunch with Owen in London, or did Carnes mistake Owen for someone else? The possibility that Bateman has been imagining his murderous adventures is available to us because there are several details and jumps in the text that allow us to feel he may have been leading a double life, or just fantasizing. These are textual ambiguities which Mary Harron's film American Psycho (2000) was able to use very effectively (Tighe 2005: 113-114).

In fact, Harron did more than just use the ambiguities effectively, she removed them altogether. The ending of the film, decidedly tips the balance firmly on the side of fantasy. This is due in great part, as Julian Murphet explains, to the inclusion of a brief shot of the violent, misogynistic drawings that Patrick has obsessively produced:

The final scene at Harry's, where Carnes destroys Patrick's claims to homicidal mania, is intercut with a scene (impossible in the terms of the book's first person narration) of Patrick's secretary Jean (Chloe Sevigny) leafing through his diary alone in his office, where she discovers an escalating number of poisonous doodles and designs devoted to the desecration of women's bodies, much like the various murders he claims to have committed. This scene clearly establishes the overriding possibility that Bateman's violence 
has all along been confined to the level of daydream and fantasy, and moreover scotches the possibility left open in the novel that he and Jean will one day find a clichèd domestic life together. After such knowledge, what forgiveness? (Murphet 2002: 77).

Murphet hits the nail on the head with his closing rhetorical question. The Bateman of the film - very much unlike the Bateman of the book - is let off the hook in the end. While Ellis's original character is at best a profoundly disturbed sociopath and at worst an actual psycho-killer, Harron's version of Patrick is really just a guy with a vivid, albeit very violent, imagination; a character flaw which is indeed quite forgivable. Moreover, Bateman's spectacularly attractive body, which is only described in the novel but displayed in all of its muscular perfection on film, also makes it much easier to forgive Patrick's minor indiscretions. As film spectators, we share Patrick's narcissistic obsession with his body. When we admire him in the mirror alongside the protagonist, we are aligned with his (auto)erotic desire. We are therefore much more inclined to accept the film's ultimate clemency towards him, since we are already visually "on his side". It is also during one of those moments of shared narcissistic desire that Patrick shows most insight about his own vacuity. In an early scene, as he/we admire him in the mirror he says:

There is an idea of a Patrick Bateman. Some kind of abstraction, but there is no real me. Only an entity - something illusory. And though I can hide my cold gaze ... and you can shake my hand and feel flesh gripping yours ... and maybe you can even sense our life styles are probably comparable, I simply am not there.

This remarkable self-awareness as to his own absence from the realm of meaningful human interaction brings the spectator closer to Patrick and again redeems him in our eyes in a way that Ellis's original never is.

I would argue that it is in this interval between the book and the film, in this rhetorical forgiveness, that "Canadianness" infiltrates itself in Harron's adaptation. While Canadian spectators would probably be as quick as their American counterparts to condemn the crimes of Patrick Bateman, they might also identify with his "Canadianness" and thus be more inclined to forgive him. Patrick's "Canadianness", as I present it here, has nothing to do with his place of birth, or with the rumours that Canadian serial killer Paul Bernardo saw Ellis' book as his "bible", or that Mary Harron's as a Canadian woman "naturally" sought to create a more "restrained" version of the novel (Mckay 2000: 12:36). Rather, what is Canadian about Patrick is precisely his self-awareness that he does not have a tangible identity, and that painting layer upon layer of post-modern Americana on his body simply does not help. The beauty products, the expensive suits, the strict physical regime, these are all signs of American cultural capital and financial power that only accentuate Patrick's lack of a definite sense of self. 
As Anthony Wilden argued in his 1980 book, The Imaginary Canadian, people living in Canada are forever trapped in a binary imaginary relationship with America. Sensing their own lack of identity, they feel compelled to construct an image of themselves in relation to the overwhelmingly powerful neighbor to the South. Either whole-heartedly embracing or utterly rejecting the signs of American imperialism, Canadians remain unavoidably entangled in US culture. While Harron's obvious satire of American materialism is representative of the latter attitude, projecting upon the States all that is negative about late capitalistic societies - including our own - our admiration for Patrick's body, his fancy clothes and his jet-setting lifestyle, represents the former where, as Canadians, we cannot help but yearn for the glittering splendor of the American Dream. But ultimately, horror for the Canadian emerges from the deep knowledge that, like Patrick Bateman, "we are simply not there."

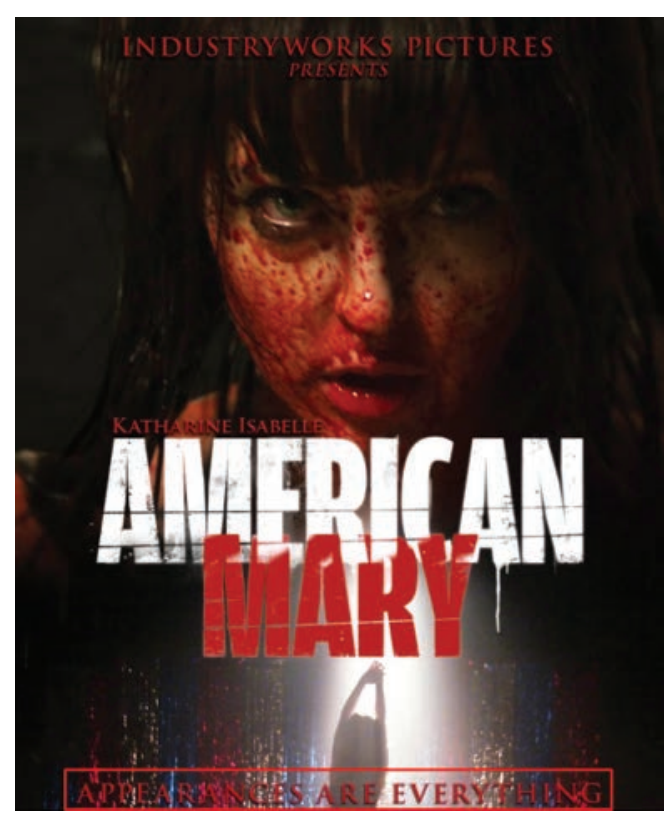

Figure 2. American Mary Poster

The title character of Jen and Sylvia Soska's American Mary is also entangled in the narrative of not being "there", but from a different perspective. Rather than being the deficient mirror of American culture like Patrick, Mary Mason (played by Katharine Isabelle of Ginger Snaps fame) is the amoral surgical instrument that modifies the body of her "patients" in ways that position them in the iconic place where they wish to be. A brilliant med-school student in dire need of cash, Mary agrees to perform a surgical operation on a woman who wishes to look exactly like a Barbie doll. Initially uncomfortable with her actions, a tragic event 
triggers a change in her ethical dilemma. Raped by one of her trusted professors, she uses her new-found skills in body-modification surgery to inflict revenge on her treacherous assailant. Shortly after, she launches a lucrative, if not entirely legal, practice where she remorselessly transforms people's bodies to realize their fantasies of whom or what they wish to look like, be it a demon or a violin. In the end, the angry boyfriend of her first client, incensed by Mary's transformation of his love object into a sexless living doll, stabs her to death.

Directed by twin sisters who have developed a significant cult following, particularly among young female fans of horror, American Mary undoubtedly functions as a feminist critique of patriarchy and its relentless distortions of the female body. However, my main interest here is less with gender, than with the "Americanness" of American Mary. Since the film's narrative does not explain the title (her nickname, we learn from the Soska sisters who make a cameo appearance in the film, is "Bloody Mary"), there has been much speculation as to why the main character's nationality appears in the title. ${ }^{6}$ The sisters themselves have provided an obvious answer:

We do poke a little bit of fun at America and American culture and their ideals of beauty and normalness [...] Plastic surgery ... it's such a bizarre American thing that you can be rich and powerful and you can have everything but you have the ability to manipulate the way you look. It's a bizarre value system and people ask us "Why American Mary"? With this story it can't not be American Mary. (Conterio 2013)

The meaningful point here is not that the film debunks America's obsession with artificial beauty, but rather that the sisters felt compelled to insist in the title that this is an American story.

There are several hints that the film is set in the US, such as close ups on American dollar bills whenever any money is exchanged, and passing references to the setting being Seattle. It is very common in English-Canadian cinema to add such references in an attempt to appease potential American spectators, who are apparently incapable of enjoying films that are not set in their country - or so Canadian film producers seem to believe. But to specify in the title that the film is set in America is a rare practice. This over-insistence on the location brings such immediate attention to the "there" of the narrative that it instantly suggests we are not there. ${ }^{7}$ Quote Marty Short: "Americans watch TV, Canadians watch American TV."

Like Patrick Bateman, Mary's clients want to don the apparels of self-confidence and assertive identity, while never fully getting there. Beatress (Tristan Risk), the most intricately developed of the "body-mod" characters has spent years investing in plastic surgery in order to look exactly like "Betty Boop". But she is "not there" ... Nowhere near, in fact. She does not look at all like Betty Boop. She just looks like a freak who is desperately trying to look like a cartoon character. Similarly, American Mary tries to look like a sleek, sexy, edgy, 
S\&M-chic independent American thriller, but it does not quite work. The sisters' previous film, Dead Hooker in a Trunk (2009), was by the directors' own admission an "ugly" film ("The Soska Sisters \& Katharine Isabelle"). They tried to over-compensate for this ugliness with the glossy American Mary. But the filmbody-modification attempt does not quite get them "there". The "seedy" strip club where Mary hangs out looks too clean and safe; the surgeons' party, where Mary is raped by one of her professors, seems very tame; the body-mod clients are all rather inoffensively shocking; and Katharine Isabelle in the role of Mary appears too sweet, quirky and diminutive to make for a convincing "rampaging hot chick killing people" ("The Soska Sisters \& Katharine Isabelle"). In other words, American Mary looks too Canadian to pass as a forceful indictment of American culture. Rather, like American Nightmare and American Psycho, it projects undo the American body its own fear about Canadian culture: obsessively trying to change your appearance to look more like iconic America can only lead to disaster.

Some forty years ago, David Cronenberg upset his compatriots with his gruesome body-horror film Shivers (1975), a shlocker explicitly set in Canada and dealing overtly with many typically Canadian obsessions. ${ }^{8}$ Self-righteous Canadians were so appalled by this grotesquely explicit display of our national flesh that they thought that "if using public money to produce films like The Parasite Murders [aka Shivers] is the only way that English Canada can have a film industry, then perhaps English Canada should not have a film industry" (Delaney, 1975: 83) To this day, there remains a similar concern that Canadian cinema should not indulge in such horrific bodily functions. While Cronenberg was undoubtedly very influential in the Canadian film industry, few Canadian filmmakers followed the practice he established in Shivers, Rabid (1977), The Brood (1979), Scanners (1981) and Videodrome (1983) of situating cinematic tales of terror in Canada. Many horror films are shot in Canada, but comparatively few are set here, probably in part to avoid the sort of criticisms that Cronenberg suffered early in his career. Therefore, the three horror films examined here are far from unique in projecting Canadian fears unto the US landscape. They do stand out, however, by their insistence on naming America in their titles. In this way, they expose the cultural displacement of their corporeal obsessions. The repressed always returns! Admittedly, there has been an improvement over the past decade with an increasing number of filmmakers, especially in Quebec, willing to set horror stories in their own backyards. ${ }^{9}$ But by and large, Canadians still have a long way to go before they can stop blaming the American monster for everything bad that happens to them, and finally dare to embrace their own demons.

\section{Notes}

1 See examples of this at http://www.peopleofwalmart.com.

2 See for instance, Peter Normanton (2012[1932]) The Mammoth Book of Slasher Movies. London and Philadelphia: Constable \& Robinson and Running Press. 
The expression "Toronto the Good" was coined by Montreal journalist Christopher St. George Clark in his 1898 book Of Toronto the good, a social study: the queen city of Canada as it is. On the monster as a projection of cultural anxieties see Brian Holm Sørensen (2011).

As stated in Section 91 of The Constitution Act, 1867, 30 \& 31 Vict., c.3.

6 See, for instance, the discussion on rottentomatoes.com and other blogs such as "Superscaryblog"(http//:superscaryblog.wordpress.com/2013/10/03/american-mary-canada2012/); and "Cinemademerde" (http://cinemademerde.com/American_Mary.shtml) One thinks of Denys Arcand's Le Déclin de l'empire américain (1986) which is in great part about being outside looking in, America.

8 On this topic see Handling (1983); and Beard (1994).

9 See, for instance, my own article on the recent emergence of the Quebec horror film: "Popular Genres in Quebec Cinema: The Strange Case of Horror in Film and Television." In: Beaty, Bart, Derek Britton, Gloria Filax and Rebecca Sullivan (eds.) How Canadians Communicate III: Contexts of Canadian Popular Culture. Edmonton: Athabasca University Press, 141-159.

\section{References}

“The Soska Sisters \& Katharine Isabelle." Grolsch Film Works. http://grolschfilmworks.com "This isn’t Toronto the Good anymore." National Post, 11 June 2009, A15.

"Toronto: Welcome to the Big Smog." Toronto Star, 3 June 2006, H03.

Agrell, Siri (2010) "Toronto the Good awakes to lick its wounds - The G8/G20 Summit Toronto / Weekend Of Violence" Globe and Mail, 28 June, 2010, A10.

Beard, William (1994) "The Canadianness of David Cronenberg." Mosaic 27 (2), 113-133.

Conterio, Martyn (2013) "The Soska Sisters \& Katharine Isabelle." Grolsch Film Works, http:// grolschfilmworks.com/ca/features/the-soska-sisters-katharine-isabelle. Posted July 1, 2013; accessed on January 2, 2014.

Derry, Charles (2009) Dark Dreams 2. 0: A Psychological History of the Modern Horror Film from the 1950s to the 21st Century. Jefferson, NC: McFarland.

Handling, Piers (1983) “A Canadian Cronenberg." In: Handling, Piers (ed.) The Shape of Rage. Toronto: General Publishing, 98-114.

Loiselle, André (2010) "Popular Genres in Quebec Cinema: The Strange Case of Horror in Film and Television." In: Beaty, Bart, Derek Britton, Gloria Filax and Rebecca Sullivan (eds.) How Canadians Communicate III: Contexts of Canadian Popular Culture. Edmonton: Athabasca University Press, $141-159$.

Longfellow, Brenda (2006) "Surfing the Toronto New Wave: Policy, Paradigm Shifts and Post-Nationalism." In: Loiselle, André and Tom McSorley (eds.) Self-Protraits: The Cinemas of Canada since Telefilm. Ottawa: Canadian Film Institute, 167-200.

Malpas, Simon (2005) The Postmodern. London and New York: Routledge.

Mckay, John (2000) "Canadian director brings 'restrained' Psycho to the screen." The Canadian Press April 10, 2000, 12:36.

Micallef, Shawn (2010) Stroll: Psychogeographic Walking Tours of Toronto. Toronto: Coach House Books.

Miller, Rhett. “American Nightmare," Canuxploitation, http://www.canuxploitation.com/ review/ amnightmare.html

Murphet, Julian (2002) Bret Easton Ellis's American Psycho: A Reader's Guide. New York: Continuum, 2002.

Normanton, Peter (2012[1932]) The Mammoth Book of Slasher Movies. London and Philadelphia: Constable \& Robinson and Running Press.

Pevere, Geoff (1998) "We like to watch: 50 years of television in Canada." Take One 7 (20), Summer, 6-19. 
Sørensen, Brian. Holm (2011) Monsters: Fictional Representations of Cultural Anxieties. Copenhagen: Aalborg University.

Sutherland, Sam (2012) Perfect Youth: The Birth of Canadian Punk. Toronto: ECW Press.

Tighe, Carl (2005) Writing and Responsibility. London and New York: Psychology Press.

Wilden, Anthony (1980) The Imaginary Canadian. Vancouver: Pulp Press.

ANDRÉ LoISElle is a Professor of Film Studies at Carleton University, Ottawa. His main areas of research are Canadian and Québécois cinema, theatricality in cinema and the horror film. He has published ten books, including Stages of Reality: Theatricality in Cinema (2012, with Jeremy Maron), Denys Arcand's 'Le Déclin de l'empire américain and 'Les Invasions barbares' (2008), Cinema as History: Michel Brault and Modern Quebec (2007) and Canada Exposed (2009, with Pierre Anctil and Christopher Rolfe). He is currently working (with Gina Freitag) on an anthology entitled Terror of the Soul: Essays on the Canadian Horror Film.

Address: Prof. Dr. André Loiselle, School for Studies in Art and Culture, 423 St Patrick's Building, Carleton University, 1125 Colonel By Drive, Ottawa ON, K1S 5B6, Canada. [email: Andre.Loiselle@carleton.ca] 